\title{
Effects of Irrigation and Soil Types on the Germination and Growth of Okra (Abelmoschus esculentus L. Moench)
}

\author{
Modupe Janet Ayeni ${ }^{*}$, Oluwakemi Elizabeth Ale, Joshua Kayode \\ Department of Plant Science, Ekiti State University, Ado-Ekiti, Nigeria \\ Email address: \\ jayeni@yahoo.com (M. J. Ayeni), kemiwealth89@gmail.com (O. E. Ale), jokayode@ymail.com (J. Kayode)
}

To cite this article:

Modupe Janet Ayeni, Oluwakemi Elizabeth Ale, Joshua Kayode. Effects of Irrigation and Soil Types on the Germination and Growth of Okra (Abelmoschus esculentus L. Moench). Journal of Plant Sciences. Vol. 3, No. 2, 2015, pp. 59-63. doi: 10.11648/j.jps.20150302.13

\begin{abstract}
Okra (Abelmoschus esculentus L. Moench) planted in three different soil samples were subjected to three different watering treatments to examine the effects of irrigation and soil types on the germination of okra, an important crop in Nigeria. Germination of okra seeds occurred best in cultivated soil with highest values in height $(55.70 \mathrm{~cm})$, leaf area $\left(607.62 \mathrm{~cm}{ }^{2}\right), \mathrm{dry}$ roots $(0.98 \mathrm{~cm})$ and shoot $(5.26 \mathrm{~cm})$ weights under every 2 days watering interval. The degraded soil had lowest values in all the parameters assessed.Statistical analysis (ANOVA, $\mathrm{P}<0.05$ ) revealed that there were no significant differences in effects of irrigation and soil types on the germination, number of leaves with dry root and shoot weights. Significant differences abound in the heights, leaf area, and fresh root and shoot weights on the irrigation frequencies and soil types at 5\% level of significance.
\end{abstract}

Keywords: Irrigation, Soil Types, Okra, Abelmoschus esculentus, Germination

\section{Introduction}

The current increase in population worldwide due to urbanization and industrialization reduced land coverage that has adverse effects on agricultural practices. This had resulted to scarcity in agricultural products such as food and forestry products. The millennium goal of food for all is being hindered. The available lands in the tropical regions need irrigation to improve economic returns to production of crops more than $100 \%$. Irrigation practices are to complement or substitute the available water from natural sources such as rainfall, flood, dew and ground water. [1] reported that irrigation is needed in most parts of West Africa where there may be a prolonged drought period and mostly where water from natural sources is inadequate for effective crop germination and production.

According to [2] the current demographic trends and future growth projections as much as $60 \%$ of the global population may suffer water scarcity by the year 2025. Irrigation of croplands by drainage is to supply the entire field uniformly with water so that each plant has the amount of water it needs [3]. [4] reported the surface irrigation to be the common method on agricultural lands. [5] also reported that in a localized irrigation system water is distributed under low pressure through piped network and applied as a small discharge to each plant. [6] noted that central pivot irrigation is used in all parts of the world which suite all types of terrain but the manual watering or bucket watering is usable for small scale farmers.

[7] reported empirical agricultural models of the choice of irrigation to examine how they are influenced by climate. Irrigation of farmlands can enhance sustainability of agricultural production for food. Control irrigation is essential for high yield because the crop is sensitive to both over and under irrigation. Scheduling water application is very critical to make proper yield of the crop as excessive irrigation reduces yield, inadequate irrigation causes water stress and reduces production. The role of irrigation at proper level and stage of plant yield of crops had been reported [8].

Okra is a crop in the family Malvaceae which is widely eaten in South Western Nigeria for its edible fruit which is rich fibre, vitamin $\mathrm{C}$, and folate content. It is also a good source of calcium and potassium.

\section{Materials and Methods}

\subsection{Collection of Samples}

A greenhouse experiment was conducted in the Department of Plant Science, Ekiti State University, Ekiti State Nigeria, between May and July 2011. Okra seeds were 
obtained from Ekiti State Agricultural Development Project (ADP), Ado -Ekiti. Soil samples were collected at $10 \mathrm{~cm}$ deep from three sites, 2 years old fallow land, a cultivated maize farmland land and a degraded land from a degraded land from a construction site. [9] had earlier provided the climatic and edaphic conditions of the study area.

\subsection{Experimental Design}

Equal amount of the three different types of soils was weighed into 15 planting pots each. The 15 pots were divided into three with each containing 5 replicates according to watering regimes (Daily watering, 2days watering and 3days watering respectively) and was laid down in Complete Randomized Design (CRD). Five seeds were sown in each pot and watering was done accordingly (daily, 2days and 3 days) with $200 \mathrm{ml}$ of water either early in the morning or late in the evening. The seeds were considered germinated upon plumule emergence. Emergence counts were recorded daily until no further emergence was observed. The velocity of germination (COV) was determined according to [10] as:

$$
C O V=\frac{A_{1}+A_{2}+A_{3}+\cdots A_{n}}{A_{1} T_{1}+A_{2} T_{2}+A_{3} T_{3}+\cdots A_{n} T_{n}} \times \frac{100}{1}
$$

Where: $A=$ Number of okra seedlings that emerged in a particular day, and $\mathrm{T}$ is the number of days involved.

At three weeks after planting, the seedlings were thinned to one plant per pot. Weekly heights of seedlings were measured for eight weeks. At the end of the eighth week, parameters such as number of leaves at harvest and longest leaf, fresh and dry root and shoot weights were recorded. The growth parameters determined are: leaf area according to [11] as:

\section{$\mathrm{A}=\mathrm{L} \times \mathrm{B} \times 0.75 \times 2$}

Where: $\mathrm{A}=$ Area of the leaf, $\mathrm{L}=$ Length of the leaf, $\mathrm{B}=$ Breath of the leaf and $0.75=$ a constant.

The Relative Growth Rate (RGR) of the plants were determined according to $[12,13]$ as :

$$
R G R=\frac{L n \cdot H_{2}-L n \cdot H_{1}}{T_{2}-T_{1}}
$$

Where: $\mathrm{H}_{2}=$ final height of the plant, $\mathrm{H}_{1}$ = initial height of the plant, $\mathrm{T}_{2}=$ Final time and $\mathrm{T}_{1}=$ initial time and $\mathrm{Ln}=$ natural Log.

The plants were carefully uprooted and washed thoroughly and were separated into roots and shoots. The fresh weights of the roots and shoots were weighed using Electronic Top Loading Digital balance; G\& G model JJ 300Y.China.They were properly tagged and kept in the herbarium of Plant Science Department, Ekiti State University for three weeks to obtain the dry weights.

\subsection{Data Analyses}

The means from the results of the parameters studied were subjected to One - Way Analysis of Variance (ANOVA, P < 0.05) using Statistical Package for Social Sciences (SPSS) version 15 (2009) computer software. Duncan Multiple Range Test (DMRT) at 5\% level was used as follow up the test to separate the means.

\section{Results and Discussion}

The effects of irrigation on the germination of okra under the three soil samples were shown in Table 1. Okra germinated in the three soil types. The highest percentage of okra germination in the three soil samples occurred in fallow soil in daily watering (96\%) and the lowest germination occurred in 4days watering $(68 \%)$. Degraded soil sample recorded the highest germination at every 2 days watering $(84 \%)$, while the least germination occurred in 4days watering.

Statistical analysis $(\mathrm{P}<0.05)$ showed that there were no significant differences in the germination of okra seeds on different soil samples under different watering regimes. This was in accordance with the work of [14] who reported that there was no significant difference among irrigation treatments in terms of panicle number per $\mathrm{m}^{2}$ and panicle length of foxtail millet.

The Coefficient of Velocity (COV) of okra seed germination was shown in Table 2. In the three soil samples, the highest COV of okra seeds occurred in degraded soil with 4 days watering. The least COV of the okra seed occurred at daily watering in cultivated soil. Statistical analysis $(\mathrm{P}<0.05)$ showed that there were no significant differences in the speed of germination (COV) of okra seeds on different soil samples under different watering regimes.

The weekly growth in heights of okra seedlings following different watering treatments in the three samples were shown in Table 3. The results showed that the rate of growth was directly proportional to the frequency of watering in the all the soil types. At the end of eighth week, the highest mean value of okra growth occurred at cultivated soil under 2 days watering $(55.70 \mathrm{~cm})$. The least growth occurred at degraded soil under daily watering $(28.30 \mathrm{~cm})$. This tried to suggest that okra might not need daily watering for improve growth and yield. Statistical analyses $(\mathrm{P}<0.05)$ revealed that the growth of okra from different watering regimes were not significantly different in the seventh and eighth week. Significant differences abound in the okra growth up to the sixth week.

The effects of irrigation frequency on the number of leaves of okra are shown in Table 4. The highest mean value of okra leaves occurred in cultivated and fallow soil at 4 days watering (7.60). The least okra leaves occurred in degraded soil both at daily and two says watering (4.80). This tried to suggest that degraded soil might lack some essential nutrients that hindered vegetative growth of okra. Statistical analyses $(\mathrm{P}<0.05)$ showed that there were no significant differences in number of leaves of okra on different soil samples under different watering regimes.

The effects of irrigation frequency on the leaf area of okra 
are shown in Table 5. The results revealed that the highest leaf area of okra occurred in fallow soil with 4 days watering $\left(633.87 \mathrm{~cm}^{2}\right)$. The least mean value occurred in degraded soil at daily watering $\left(163.26 \mathrm{~cm}^{2}\right)$.Statistical analyses $(\mathrm{P}<0.05)$ revealed that the results from different watering regimes were not significantly different except 4days watering in cultivated soil that showed significant difference. These findings revealed that okra might not require much water as the 4 days watering had larger number of leaves and leaf area. This finding was not in accordance with the work of [15] who noted that the number of leaf and leaf area was significantly reduced as water stress increased. Also [16] reported that irrigation frequency had significant effects on number of leaf and leaf area of Myrobian seedlings

The biomass production of okra in different soil samples following three watering regimes are shown in Table 6 . The results showed that the highest mean fresh shoot weight occurred in cultivated soil at 4days watering (39.93g). The least value for fresh shoot occurred in in degraded soil in daily watering $(5.89 \mathrm{~g})$. For the fresh root weights, the highest mean value occurred in cultivated soil at 4 days watering $(3.78 \mathrm{~g})$. The least fresh root weights degraded soil in degraded soil at daily watering. For the dry shoot weights, the highest mean value occurred in cultivated soil at 2 days watering $(0.98 \mathrm{~g})$. The least occurred in degraded soil at daily watering $(0.46 \mathrm{~g})$.

Statistical analyses $(\mathrm{P}<0.05)$ showed that there were no significant differences in the fresh and dry root weights of okra for the different watering regimes except 2 days watering in cultivated soil that showed significant difference in fresh shoot weights. Although, it was revealed that the plant grew larger with less frequent watering in the three soil types, which might suggest that the plant has lower rate of transpiration. This was not in accordance with the earlier report of [17] who noted that a reduction of weight may occur due to a lower photosynthate production, because of the excess of excessive loss of water through leaves.

Irrigation of agricultural crops had earlier being reported by earlier researchers such as [8] who revealed that controlled irrigation is essential for high yield of okra as they noted that the crop is sensitive to both over and under irrigation. It was also reported by some researchers such as $[18,3,19]$ that reducing irrigation water supply help to accomplished crop yield. This might be responsible for the highest height recorded in 4 days watering in both degraded and fallow soil in this study.

Table 1. Germination of okra in different soil samples following three different watering treatments.

\begin{tabular}{llll}
\hline & \multicolumn{3}{c}{ SOIL TYPES } \\
\hline Watering treatment & DL & CL & FL \\
\hline Everyday & $76.00 \mathrm{a}$ & $76.00 \mathrm{a}$ & $96.00 \mathrm{a}$ \\
Every 2 days & $84.00 \mathrm{a}$ & $76.00 \mathrm{a}$ & $72.00 \mathrm{a}$ \\
Every 4 days & $72.00 \mathrm{a}$ & $72.00 \mathrm{a}$ & $68.00 \mathrm{a}$ \\
\hline
\end{tabular}

Means followed by the same letter within column for each treatment are not significantly different at $\mathrm{P}<0.05$.

Table 2. Speed of germination of okra in different soil samples following three different watering treatments.

\begin{tabular}{llll}
\hline & & SOIL TYPES & FL \\
\hline Watering treatment & DL & CL & $19.40 \mathrm{a}$ \\
\hline Everyday & $21.66 \mathrm{a}$ & $18.60 \mathrm{a}$ & $19.00 \mathrm{a}$ \\
Every 2 days & $25.00 \mathrm{a}$ & $19.00 \mathrm{a}$ & $20.00 \mathrm{a}$ \\
\hline
\end{tabular}

Means followed by the same letter within column for each treatment are not significantly different at $\mathrm{P}<0.05$.

Table 3. Weekly increase in seedling heights of okra in different soil samples following three different watering treatments.

\begin{tabular}{|c|c|c|c|c|c|c|c|c|}
\hline \multirow[b]{2}{*}{ Watering treatment } & \multicolumn{8}{|c|}{ Weeks } \\
\hline & 1 & 2 & 3 & 4 & 5 & 6 & 7 & 8 \\
\hline $\begin{array}{l}\text { DL } \\
\text { Everyday }\end{array}$ & $7.45 \mathrm{f}$ & $12.08 \mathrm{e}$ & $13.82 \mathrm{e}$ & $17.74 d$ & $21.70 \mathrm{c}$ & $23.94 b c$ & $26.22 \mathrm{ab}$ & $28.30 \mathrm{a}$ \\
\hline Every 2 days & $8.58 \mathrm{f}$ & $15.49 \mathrm{e}$ & $15.49 \mathrm{e}$ & $21.94 d$ & $25.42 \mathrm{c}$ & $27.80 \mathrm{bc}$ & $29.88 \mathrm{ab}$ & $32.78 \mathrm{a}$ \\
\hline $\begin{array}{l}\text { Every } 4 \text { days } \\
\text { CL }\end{array}$ & $9.96 \mathrm{e}$ & $13.91 \mathrm{de}$ & $13.91 \mathrm{de}$ & $18.54 \mathrm{~cd}$ & $22.54 \mathrm{bc}$ & $24.90 \mathrm{~b}$ & $28.00 \mathrm{ab}$ & $32.62 \mathrm{a}$ \\
\hline Every 2 days & $8.20 \mathrm{f}$ & $12.67 \mathrm{ef}$ & $16.55 \mathrm{e}$ & $23.10 \mathrm{~d}$ & $28.30 \mathrm{c}$ & $34.56 b$ & $37.72 b$ & $55.70 \mathrm{a}$ \\
\hline $\begin{array}{l}\text { Every } 4 \text { days } \\
\text { FL }\end{array}$ & $4.52 \mathrm{~g}$ & $9.42 \mathrm{f}$ & $12.99 f$ & $17.40 \mathrm{e}$ & $24.74 d$ & $33.54 \mathrm{c}$ & $39.74 b$ & $54.34 \mathrm{a}$ \\
\hline Everyday & $7.89 \mathrm{e}$ & 11.70de & $15.28 \mathrm{de}$ & 20.74de & $25.16 b c$ & $29.72 b c$ & $33.90 \mathrm{ab}$ & $39.78 \mathrm{a}$ \\
\hline Every 2 days & $8.29 \mathrm{~g}$ & $15.22 \mathrm{fg}$ & $19.97 \mathrm{ef}$ & 25.76de & $30.96 \mathrm{~cd}$ & $34.28 b c$ & $38.32 \mathrm{ab}$ & $45.28 \mathrm{a}$ \\
\hline Every 4 days & $8.61 \mathrm{f}$ & $14.22 \mathrm{ef}$ & $17.40 \mathrm{e}$ & $24.32 d$ & $31.70 \mathrm{c}$ & $36.70 \mathrm{bc}$ & $40.16 \mathrm{ab}$ & $45.04 \mathrm{a}$ \\
\hline
\end{tabular}

Means followed by the same letter within column for each treatment are not significantly different at $\mathrm{P}<0.05$. 
Table 4. Number of leaves of okra in different soil samples following three different watering treatments.

\begin{tabular}{llll}
\hline & & SOIL TYPES & \\
\hline Watering treatment & DL & CL & FL \\
\hline Everyday & $4.80 \mathrm{a}$ & $7.20 \mathrm{a}$ & $6.20 \mathrm{a}$ \\
Every 2 days & $4.80 \mathrm{a}$ & $6.60 \mathrm{a}$ & $6.40 \mathrm{a}$ \\
Every 4 days & $6.00 \mathrm{a}$ & $7.60 \mathrm{a}$ & $7.60 \mathrm{a}$ \\
\hline
\end{tabular}

Means followed by the same letter within column for each treatment are not significantly different at $\mathrm{P}<0.05$.

Table 5. Leaf area of okra in different soil samples following three different watering treatments.

\begin{tabular}{llll}
\hline & & SOIL TYPES & FL \\
\hline Watering treatment & DL & CL & $468.89 \mathrm{a}$ \\
\hline Everyday & $163.26 \mathrm{a}$ & $404.39 \mathrm{ab}$ & $598.41 \mathrm{a}$ \\
Every 2 days & $181.52 \mathrm{a}$ & $607.62 \mathrm{a}$ & $633.87 \mathrm{a}$ \\
\hline
\end{tabular}

Means followed by the same letter within column for each treatment are not significantly different at $\mathrm{P}<0.05$.

Table 6. Biomass production by seedling of okra in different soil samples following three different watering regimes.

\begin{tabular}{|c|c|c|c|c|c|c|c|c|c|c|c|c|}
\hline \multirow[t]{2}{*}{ Watering treatment } & \multicolumn{3}{|c|}{ Fresh root weight(g) } & \multicolumn{3}{|c|}{ Fresh shoot weight(g) } & \multicolumn{3}{|c|}{ Dry root weight(g) } & \multicolumn{3}{|c|}{ Dry shoot weight(g) } \\
\hline & DL & $\mathbf{C L}$ & FL & DL & $\mathbf{C L}$ & FL & DL & CL & FL & DL & $\mathbf{C L}$ & FL \\
\hline Everyday & $0.70 \mathrm{a}$ & $1.92 \mathrm{a}$ & $1.55 \mathrm{a}$ & $5.89 \mathrm{a}$ & $21.06 \mathrm{a}$ & $20.74 a$ & $0.46 \mathrm{a}$ & $0.76 \mathrm{a}$ & $0.50 \mathrm{a}$ & $1.36 \mathrm{a}$ & $3.76 \mathrm{a}$ & $3.00 \mathrm{a}$ \\
\hline Every 2 days & $1.08 \mathrm{a}$ & $3.31 \mathrm{a}$ & $2.33 \mathrm{a}$ & $8.71 \mathrm{a}$ & $28.88 \mathrm{~b}$ & $25.70 \mathrm{a}$ & $0.48 \mathrm{a}$ & $0.98 \mathrm{a}$ & $0.58 \mathrm{a}$ & $1.70 \mathrm{a}$ & $5.26 \mathrm{a}$ & $4.70 \mathrm{a}$ \\
\hline Every 3 days & $1.89 \mathrm{a}$ & $3.78 \mathrm{a}$ & $2.77 \mathrm{a}$ & $16.35 \mathrm{a}$ & $39.93 a$ & $30.86 a$ & $0.70 \mathrm{a}$ & $0.90 \mathrm{a}$ & $0.64 a$ & $2.52 \mathrm{a}$ & $5.48 \mathrm{a}$ & $7.22 \mathrm{a}$ \\
\hline
\end{tabular}

Means followed by the same letter within column for each treatment are not significantly different at $\mathrm{P}<0.05$.

\section{Conclusion}

Watering regimes had many effects on the germination and growth of okra. It was revealed from the study that okra seeds might thrive best on cultivated soil with every 4 days though the effects of soil types and watering treatments had no significant difference on its growth. It is suggest that okra might not require much water for maximum growth at the initial stage.

\section{References}

[1] Fasina, A.S. 2008. Irrigation Suitability Evaluation of Asu River Basin Soils, South eastern Nigeria. Int. J. Soil Sci., 3(1): $35-41$.

[2] Qudir, M., Sharma, B.R., Bruggeman, A., Choukr- Allah, R. and Karajeh, F. 2007.Non- convectional water resources and opportunities for water augmentation to achieve food security in water scarce countries. Agric. Water Manage, 87: 2-22.

[3] Deng, X.P., Shan, L., and Turner, N.C. 2006. Improving Agricultural water use efficiency in arid and semi- arid areas of China.Arid water management, 80: 23-40.

[4] Alh- Harbi, A.A., Al-orman, A. M. and El- Adgham, I.2008. Effect of drip irrigation level and emitters depthon okra (Abelmoschus esculentus) growth. Journal of Applied Science, 8(18): 2764- 3729.

[5] Provenzano, G. 2007. Using NYPRUS- 20 Stimulation model to evaluate wetted soil volume in sub- surface drip irrigation system. Journal of Water Management, Pp. 192- 198.

[6] Jayapiratha, M., Thushyanthy, V. and SivaKumar, S. 2010. Performance Evaluation of Okra under Drip irrigation system.
Asian Journal of Agricultural Research, 4:137-147.

[7] World Bank. 2007. Changing farm types and irrigation as an adaptation to climate change in Latin American agriculture.World Bank Policy Research Working Paper 4161. 41p World Bank, Washington, DC, United States.

[8] Singh, J., Pander, V.C and Kohh, V. P. 1990. Response of Vegetable pea to irrigation. Journal of Vegetable Science, 19: $11-15$.

[9] Kayode, J. and Franco, A.A. 2002. Response of Acacia mangium to rhizobia and arbuscular mycorrhizal fungi. Tropical Science, 42: 116-119.

[10] Kayode, J. 2000. A study of seed stock in rainforest site in Ado Ekiti region, Nigeria. Bioscience Research Communication, 12 (3): 325-339.

[11] Kayode, J. 2000. A study of seed stock in rainforest site in Ado Ekiti region, Nigeria. Bioscience Research Communication.12 (3): 325-339.

[12] Hoffmann, W.A. and Poorter, H. 2002. "Avoiding Bias in Calculating Relative Growth Rate. Annals of Botany", 90(1): 37.

[13] Kayode, J. and Tedela, P.O. 2005. Effects of irrigation frequency on growth and nodulation of Leucaena leucocephala. Pakistan Journal of Forestry, 554(1): 33-40.

[14] Hassan, H. 2012.Alternate Furrow Irrigation Effect on Yield, Yield Components and Seed Germination of Foxtail Millet (Setaria italica) In Double Cropping System. International Research Journal of Applied and Basic Sciences, 3(1): 64-69.

[15] Daneshimandi, M.S.H. and Azizi, M. 2008. The study on the effect of water stress and Super Absorbent polymer (S.A.P.) on some quantity and quality characteristics of Sweet basil (Ocimum basilicum L. varkeshkenylevelu).Proc. $6^{\text {th }}$ Congr. Hort. Sci., Pp. 1276-1279. 
[16] Dauda, T.O., Asiribo, O.E., Akinbode, S.O., Saks, J.O. and Salahu, B.F.2009. An assessment of the roles of irrigation farming in the millennium development goals. African Journal of Agricultural Research, 4(5): 445-450.

[17] Rauf, S. 2008.Breeding sunflower (Helianthus annuus L.) for drought tolerance. Comm. Bio. Crop Sci., 3: 29-44.
[18] Shaaban, S. M. 2006. Effect of organic and inorganic Nitrogen fertilizer on wheat plant under water regimes. Journal of Applied Science Research, 2(10): 650-656.

[19] Metin, S.S., Yazcer, A. and Eker, S. 2006. Effect of drip irrigation regimes on yield and quality of field grown.Journal of Water Management, 81: 115-131. 